\title{
FINAL DESTINATION OF CADMIUM FOUND IN CONTAMINATED SEWAGE SLUDGE IN MAIZE-CULTIVATED RED NITOSOIL
}

\author{
Ervim Lenzi ${ }^{1 *} ;$ Sílvia Naves de Souza ${ }^{1}$
}

1 Chemistry Department - Agrochemistry and Environment Lababoratory, State University of Maringá. Avenida Colombo, 5790, CEP - 87020-900, Maringá, PR Brazil *Author for correspondence<elenzi@maringá. com.br>

\begin{abstract}
Remains of human activity, such as sewage sludge, caused by population growth, are a challenge to the environment and need urgent solutions. Cadmium from contaminated biosolid (sewage sludge) in Red Nitosoil, in PVC tubes $(10 \mathrm{~cm}$ diameter and $80 \mathrm{~cm}$ height) located in greenhouse, has been analyzed. Natural biosolid in one treatment (control), cadmium-contaminated biosolid in two treatments $(2,500$ and 5,000 $\left.\mu \mathrm{g} \mathrm{g}^{-1}\right)$; cadmium-and lead-contaminated biosolid in other two treatments $(2,500 \mathrm{Cd}+$ $2,500 \mathrm{~Pb}$ and $5,000 \mathrm{~Pb} \mu \mathrm{g} \mathrm{g}^{-1}$ respectively) were added to the $0-20 \mathrm{~cm}$ soil surface layer. Maize was the test plant in the triple replication experiment. The aerial part of maize plants, samples of surface soil $(0-20 \mathrm{~cm})$ and that within the tubes, divided into internal and external samples of each tube, were harvested seventy-five days after sowing. After the preparation and nitropercloric digestion of samples, $\mathrm{Cd}$ concentrations were measured by atomic absorption spectrometry. Cd concentrations in maize were within phytotoxic tolerance. There was no significant difference among treatments in the production of plant dry matter. Highest $C d$ concentration was found in the $0-20 \mathrm{~cm}$ soil layer and differed significantly from the rest.
\end{abstract}

Key words: heavy metal; percolation; organic residues; pollution; cadmium.

RESUMO: Os resíduos da atividade antróprica em sociedade, como o lodo de esgoto, são desafios ambientais do crescimento demográfico que necessitam soluções. Com este objetivo foi estudado o destino do cádmio do lodo de esgoto (biossólido) contaminado em Nitossolo Vermelho, em casa de vegetação, em tubos de PVC $110 \mathrm{~cm}$ de diâmetro e $80 \mathrm{~cm}$ de altura). À camada superficial de 0 a $20 \mathrm{~cm}$ foi incorporado: o biossólido natural num tratamento (testemunha); biossólido contaminado com cádmio em dois tratamentos (2.500 e $\left.5.000 \mu \mathrm{g} \mathrm{g}^{-1}\right)$; e contaminado com cádmio mais chumbo em outros dois tratamentos $\left(2.500 \mathrm{Cd}+2.500 \mathrm{~Pb}\right.$ e $5.000 \mathrm{Cd}+5.000 \mathrm{~Pb} \mu \mathrm{g} \mathrm{g} \mathrm{g}^{-1}$, respectivamente). No experimento com três repetições foi usado o milho como planta teste. Após 75 dias da semeadura coletaram-se: a parte aérea das plantas de milho, as amostras de solo da superficie $(0-20 \mathrm{~cm})$ e dos tubos-sonda que foram divididas em amostra interna $e$ amostra externa de cada tubo-sonda. Após a preparação e digestão nitro-perclórica das amostras, as leituras das concentrações de Cd foram feitas pelo método de espectrometria de absorção atômica. As concentrações de $\mathrm{Cd}$ nas plantas de milho apresentaram-se dentro dos limites fitotóxicos. Na produção de massa seca das plantas não houve diferença significativa entre os tratamentos. No solo, a maior concentração de Cd foi encontrada na camada de 0-20 cm, que, diferenciou-se significativamente das demais. 


\section{INTRODUCTION}

Mankind learned by experience that soil produced less and less when continually cultivated. Consequently humans started to adopt certain agricultural practices, currently still in use, such as manuring, liming, crop rotation and others ${ }^{1}$. The addition of fertilizers to soil provides important nutrients to plants, namely, nitrogen $(N)$, phosphorus $(\mathrm{P})$ and potassium $(\mathrm{K})$ which may be in default in the soil ${ }^{2}$.

Population growth and the subsequent appearance of urban centers provided the dumping of human residues produced by development. Needless to say, this gives rise to environmental pollution that affects the general biota and man himself $f^{3,4}$. Urban sewage $^{5}$, whose treatment causes sewage sludge ${ }^{6}$, also known as biosolid, is of special importance. Through their penetration into the soil its components form a chain in the cycle and influence all forms of life. Pollutants, known as heavy metals ${ }^{7}$, are among their components. Cadmium, the heavy metal currently under analysis, has been added to the environment in significant quantities with residues of mining, foundries, industrial refuse, sewage sludge and others ${ }^{8}$. On the other hand, studies are extant on the possibility of using sewage sludge in agriculture as organic manure even though it may have been contaminated by heavy metals ${ }^{9,10,11}$.

$\mathrm{Cd}$ is naturally encountered in the soil as the product of rock meteorism whereby it is released. Under heavy oxidization cadmium oxidized mineral forms are $\mathrm{CdO}$ and $\mathrm{CdCO}_{3}{ }^{12}$ and its most important valence in the natural environment is $2+$.

In soil solution $\mathrm{Cd}^{2+}$ is rapidly divided among the mineral, organic and solution phases. In fact, $\mathrm{Cd}^{2+}$, and probably other metallic ions such as $\mathrm{Zn}^{2+}$, is associated with water and forms a hydration complex. Ion $\mathrm{Cd}^{2+}$ is Lewis's strong acid and, associated with humidity, may cause the dissociation of protons. Cd may also exist in soil solution as a complex ion associated with other ligands. In soil solution the most important compounds are $\mathrm{Cl}^{-}, \mathrm{SO}_{4}{ }^{2-}, \mathrm{HCO}_{3}{ }^{-}$, or organic links. $\mathrm{Cd}$ may also combine itself with ammonia ions in the form of $\left[\mathrm{Cd}\left(\mathrm{NH}_{3}\right)\right]^{2+}{ }_{\text {(aq) }}$ or $\left[\mathrm{Cd}\left(\mathrm{NH}_{3}\right)_{2}\right]^{2+}{ }_{\text {(aq) }}{ }^{13}$.

Brams and Anthony ${ }^{14}$ analyzed cadmium absorption by wheat during a six-year period after addition of $\mathrm{CdCl}_{2}$, concentration $7.5 \mathrm{~kg} \mathrm{ha}^{-1}$, to the soil. They noticed that concentration of cadmium greatly decreased in time. Data also indicated that $80 \%$ of Cd added was never recovered and failed to be detected up to $75 \mathrm{~cm}$ deep. The authors suggested that $\mathrm{Cd}$ was lost at the soil surface or at the soil sub-surface through the movement of soil particles.

Using doses 0,20 and $40 \mathrm{tha}^{-1}$ of sludge complemented with 60,80 and $100 \mathrm{~kg}$ $\mathrm{ha}^{-1}$ of N, P and K respectively, Silva $(1995)^{15}$ observed a linear increase in sugar cane production during the first year and did not detect any traces of heavy metals in the sugarcane broth.

Studies on the use of biosolids in soil for a variety of purposes ${ }^{9,10}$ are extant. There is, however, no agreement on the adequate dose for each culture, for each type of soil, for each type of climate, etc. This is perhaps due to difficulties in foreseeing the behavior of metals in different soil types and the nutrition requirements of each culture.

The current study analyzes the behavior of cadmium in contaminated sewage sludge applied to Red Nitosoil and its influence on maize culture. 


\section{MATERIALS AND METHODS}

\section{Soil}

Red Nitosoil soil was collected in the region of the city of Maringá, PR, Brazil. Sampling occurred at depths $0-20,20-40,40-60$ and $60-80 \mathrm{~cm}$. Samples were placed separately in packages, taken to greenhouse and used in the experiment according to the exact positions in which they had been removed from the soil.

Table 1 shows chemical results of the soil's surface layer or arable section used $(0-20 \mathrm{~cm}$ deep $)$ prior to any treatment.

Table 1. Chemical characteristics of Red Nitosoil, $0-20 \mathrm{~cm}$ deep layer, used in experiment.

\begin{tabular}{|c|c|c|c|c|c|c|c|c|}
\hline Soil & $\mathrm{Cd}\left(\dagger^{\prime}\right)$ & $\mathrm{Pb}(t)$ & $\mathrm{Fe}(\mathrm{t})$ & $\mathrm{Cu}(t)$ & $\operatorname{Mn}(t)$ & Argila( & silt( $(t)$ & $\operatorname{sand}(\mathfrak{t})$ \\
\hline & & & & & & & $\%$ & \\
\hline $\mathrm{RN}\left({ }^{*}\right)$ & 4,50 & 39.2 & 119 & 25.9 & 448 & 52.0 & 27.0 & 21.0 \\
\hline
\end{tabular}

(*) RN Red Nitosoil; ( $\dagger$ ) determination by atomic absorption spectrometry after nitric-perchloric digestion; ( $\ddagger$ ) Folk's granulometric classification ${ }^{43}$ and calculation with method suggested by Suguio ${ }^{44}$.

Table 2 shows characteristics of soil fertility of Red Nitosoil soil, layer $0-20 \mathrm{~cm}$ depth, used in the experiment.

Table 2. Fertility of Red Nitosoil by chemical analysis (*).

\begin{tabular}{|c|c|c|c|c|c|c|c|c|c|c|}
\hline \multirow[t]{2}{*}{ Soil } & \multicolumn{2}{|c|}{$\mathrm{pH}$} & \multirow{2}{*}{$\begin{array}{l}\mathrm{Al}^{3+} \\
\longleftarrow\end{array}$} & $\mathrm{H}^{+}+\mathrm{Al}^{3+}$ & \multirow{2}{*}{$\begin{array}{c}\mathrm{Ca}^{2+} \\
\mathrm{cmol}_{\mathrm{c}} \mathrm{dm}^{-3}\end{array}$} & \multicolumn{2}{|c|}{$\begin{array}{ll}\mathrm{Mg}^{2+} & \mathrm{K}^{+}\end{array}$} & \multirow{2}{*}{$\begin{array}{c}P \\
\left(\mu \mathrm{g} \mathrm{g}^{-1}\right)\end{array}$} & \multirow{2}{*}{$\begin{array}{c}C \\
(\%)\end{array}$} & \multirow[t]{2}{*}{ CTC } \\
\hline & $\left(\mathrm{H}_{2} \mathrm{O}\right)$ & $\left(\mathrm{CaCl}_{2}\right)$ & & 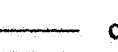 & & & $\longrightarrow$ & & & \\
\hline TR & 5,90 & 5.10 & 0.00 & 4.96 & 6.20 & 1.82 & 0.53 & 3.0 & 2.24 & 13.51 \\
\hline
\end{tabular}

(*) Techniques: 1) $\mathrm{pH}$ in $\mathrm{CaCl}_{2} 0,010 \mathrm{~mol} \mathrm{~L}^{-1}$ and $\mathrm{pH}$ in $\mathrm{H}_{2} \mathrm{O} 1: 2,5 ; 2$ ) extractor Mehlich for $\mathrm{K}$ and $\mathrm{P} ; 3$ ) extractor $\mathrm{KCl} 1 \mathrm{~mol} \mathrm{~L}-1$ for $\mathrm{Ca}^{2+}, \mathrm{Mg}^{2+}$ and $\left.\mathrm{Al}^{3+} ; 4\right)\left[\mathrm{H}^{+}+\mathrm{Al}^{3+}\right]$ method of SMP.

\section{Sewage sludge, its properties and preparation}

The Paraná Water Company (SANEPAR), Maringá sector, provided the sewage sludge which was collected at the Maringá Sewage Treatment Plant (ETE-2). The sludge was dried, ground and homogenized before analysis. After nitric-perchloric digestion of the samples, concentrations of $\mathrm{K}, \mathrm{Ca}, \mathrm{Mg}, \mathrm{Cu}, \mathrm{Zn}, \mathrm{Fe}, \mathrm{Mn}, \mathrm{Pb}$ and $\mathrm{Cd}$ were obtained by atomic absorption spectrometry ${ }^{16}$. Whereas $\mathrm{N}$ concentration was evaluated by Kjeldahl method ${ }^{17}, \mathrm{P}$ was determined by UV-Vis spectrophotometry of the phosphorus-molybdenum complex ${ }^{18}$. Determination of $\mathrm{C}$ occurred by oxidation of organic matter by $\mathrm{K}_{2} \mathrm{Cr}_{2} \mathrm{O}_{7}$ in excess and in a concentrated sulfuric acid medium and posterior excess titration of potassium dichromate ${ }^{19}$. Table 3 shows mean values obtained from analyses in triple.

Humidity and liming (dry) of sewage sludge were undertaken immediately on reception, $\mathrm{pH}$ was corrected to approximately 6.0 by a mixture of calcium carbonate and magnesium carbonate in the proportion of $3: 1$. Quantity of lime added was determined by calibration curve $\mathrm{e}^{20}$. 
SOUTH. BRAZ. J. CHEM., Vol. 11, № 12, 2003

Table 3. Chemical characteristics of original sewage slime (without chemical treatment) in experiment.

\begin{tabular}{ccccccccccccccc}
\hline Material & $\mathrm{N}$ & $\mathrm{P}$ & $\mathrm{K}$ & $\mathrm{Ca}$ & $\mathrm{Mg}$ & $\mathrm{S}$ & $\mathrm{C}$ & $\mathrm{Cu}$ & $\mathrm{Zn}$ & $\mathrm{Fe}$ & $\mathrm{Mn}$ & $\mathrm{Pb}$ & $\mathrm{Cd}$ \\
& $\longleftarrow$ & & & & $\%$ & & & & & & & & & \\
\hline Lodo(*) & 2.92 & 0.82 & 0.18 & 3.08 & 1.02 & 0.32 & 24.3 & 146 & 1327 & 6128 & 262 & 122 & 3.50 \\
\hline
\end{tabular}

$\left(^{*}\right)$ sewage sludge (biosolid).

Further, part of the sewage sludge was kept in its natural state, without any contamination, for control treatment; another part was contaminated by $\mathrm{Cd}$ (using $\mathrm{CdCl}_{2}$ ) in $\mu \mathrm{g} \mathrm{g}^{-1}$, in 2,500 and 5,000 concentrations; still another part was contaminated by a mix of cadmium and lead, in $\mu \mathrm{g} \mathrm{g}^{-1}$, in $2,500(\mathrm{Cd})+2,500(\mathrm{~Pb})$ and $5,000(\mathrm{Cd})+$ $5,000(\mathrm{~Pb})$ concentrations respectively. Lead was added as a possible interference factor in the behavior and final destination of cadmium in the system. Consequently sewage sludge was prepared for its incorporation to the arable soil layer $(0-20 \mathrm{~cm})$.

\section{PVC (polyvinyl chloride) tube}

Figure 1 shows PVC tubes $(10 \mathrm{~cm}$ diameter and $80 \mathrm{~cm}$ high) for used the experiment. Two series of gauge tubes were placed laterally, perpendicularly and diametrically opposite in the PVC tubes, at $10 \mathrm{~cm}$ depth, starting from $20 \mathrm{~cm}$ off the surface, as shown in Figure 1 - Part A. Gauge tubes collected soil samples at several depths without any damage to PVC tube or displacement of the soil column in the tube. Malleable plastic gauge tubes were fixed under pressure so that half remained in the interior of the PVC tube and the other half outside, with lid, as shown in Figure 1 - Part $B$. The inner side of the gauge tube was completely perforated with small holes so that soil solution could penetrate the gauge tube, or rather, percolate and diffuse itself throughout the soil and throughout that in the external part, as shown in Figure 1 - Part B. The existence of percolation and diffusion of the heavy metal cadmium could be verified at this sector.

\section{Building, implantation and conduction of experiment}

Three PVC tubes with gauge tubes were first prepared (Figure 1); they formed three replications for each type of sludge contamination. A total of $3 \times$ (4 contaminations $)+3 \times(1$ control $)=15$ PVC tubes was used.

A plastic screen was tied at the base and on the outside of each PVC tube to hold the soil in place and release the soil solution. Soil corresponding to the $60-80 \mathrm{~cm}$ layer was placed in each PVC tube together with the gauge tubes (e) filled with the same soil (Figure 1-Part A). Identical process was used for the 40 - 60 layer soil with the respective gauge tubes $(\mathrm{d}, \mathrm{c})$ and for the $20-40 \mathrm{~cm}$ layer soil with the respective gauge tubes $(b, a)$.

Sewage sludge contaminated with a $6 \mathrm{tha}^{-1}$ was added prior to placing the $0-20$ layer soil in the PVC tubes, for each of the four types of contaminations above. This amounted to the following: 3 tubes with control (manured soil without pollutant); 3 tubes with contaminated soil containing $\mathrm{Cd} 2,500 \mu \mathrm{g} \mathrm{g}^{-1} ; 3$ tubes with contaminated soil containing mixture of $\mathrm{Cd} 2,500 \mathrm{mg} \mathrm{g}^{-1}+\mathrm{Pb} 2,500 \mu \mathrm{g} \mathrm{g}^{-1} ; 3$ tubes with contaminated soil containing a mixture of $\mathrm{Cd} 5,000 \mu \mathrm{g} \mathrm{g}^{-1}+\mathrm{Pb} 5,000 \mu \mathrm{g} \mathrm{g}^{-1}$. 


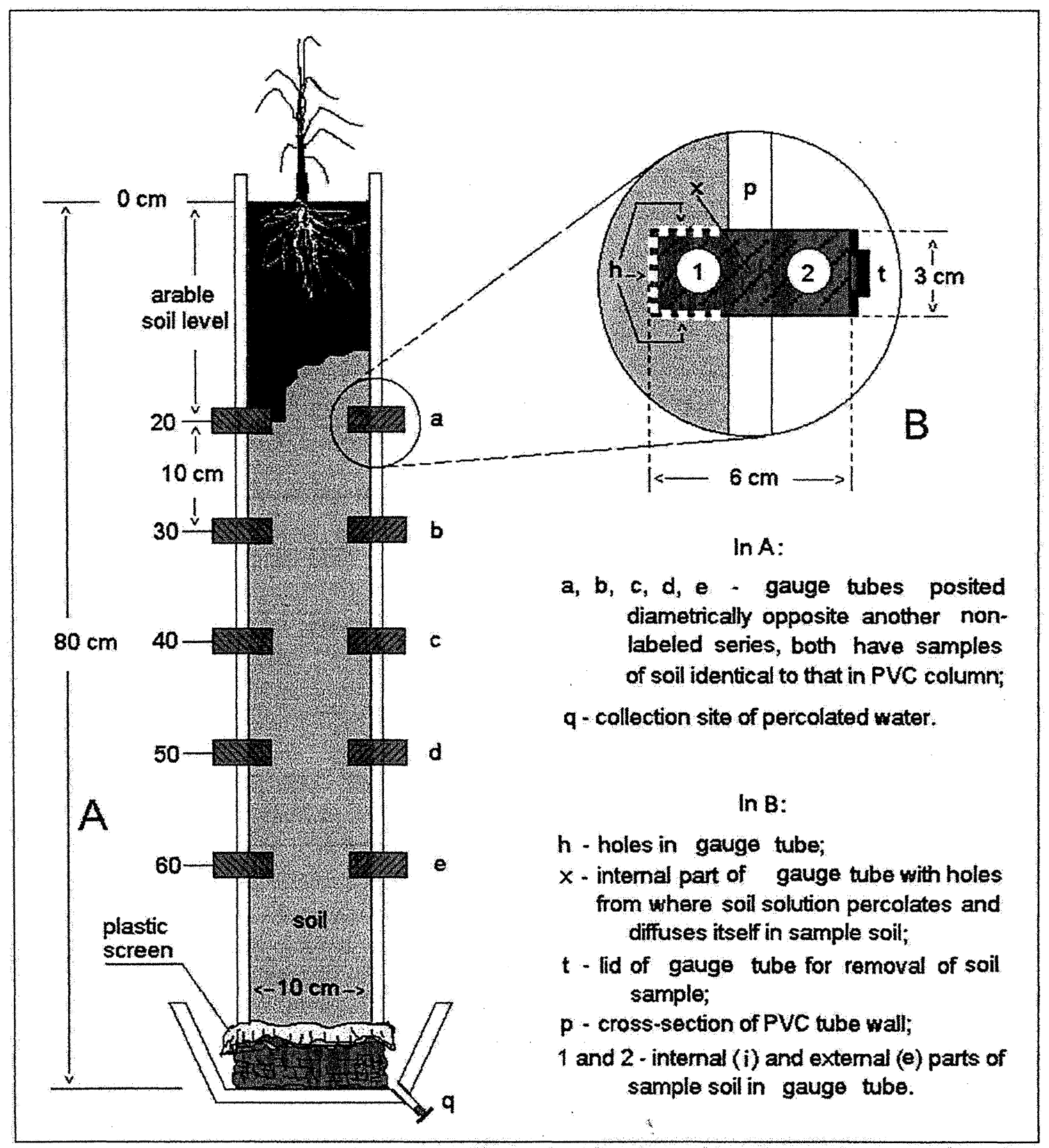

Figure 1. PVC tube (10 cm diameter; $80 \mathrm{~cm}$ high) with soil and test plant - maize: A frontal vertical cut shows different soil layers and gauge tubes $(\mathbf{a}, \mathbf{b}, \mathbf{c}, \mathbf{d}, \mathbf{e}) ; \mathbf{B}-$ amplification of frontal cut of gauge tube showing holes through which soil solution may percolate and diffuse itself through sampled soil in the internal (1) and external (2) parts.

After introducing non-contaminated (control) and contaminated sewage sludge in the first soil layer of each tube, the mixture was incubated for approximately 15 days, with humidity of each tube at $70 \%$ of field capacity and a $6.0 \mathrm{pH}$ or whereabouts.

At the end of preparations for the experiment, 5 seeds of maize BR 300 were sown per vase. Pruning occurred with two plants per vase. 
Tubes with maize plants were kept in a greenhouse. Plants were watered daily and position changes of tubes were done weekly at random. Watering occurred every seven days and double the amount of highest rainfall in the last 25 years in the region of Maringá $(151.5 \mathrm{~mm})^{21}$ was provided to percolate contaminant cadmium. Percolated solution was collected (Figure 1 - Part A), acidified at $\mathrm{pH}<2$ with concentrated nitric acid and cadmium contents analyzed by atomic absorption spectrometry after preconcentration by volume reduction in a water-bath.

\section{Sample collection and analyses}

Harvest of plants (aerial part) was done two and a half months after sowing, all at the same time; plants were washed and dried naturally and separately according to their distribution in vases. They were then placed in a buffer at $80^{\circ} \mathrm{C}$ for 48 hours $^{22}$; weighted (Table 4) and ground in a Marconi MA 048 grinding machine. Plant samples (each formed by a set of plants) for analysis totaled 15 .

A week after harvest soil samples from the $0-20 \mathrm{~cm}$ layer and from the gauge tubes were removed. The latter were divided into two parts, or rather, the internal part (i), corresponding to soil of the gauge tube placed within the PVC tube, and the external part (e) in which possible diffusion of the pollutant was analyzed. This totaled 150 soil samples of gauge tubes and 15 corresponding to the $0-20 \mathrm{~cm}$ layer.

Soil and plant samples, ground and dried at constant mass, were then decomposed by nitrate perchloride digestion.

Cadmium concentrations of the respective samples in duplicates were obtained by atomic absorption spectrometry, flame mode, according to handbook calibration rules and instructions by Welz \& Sperling ${ }^{23}$. Atomic absorption spectrometer CG model AA $7000 \mathrm{ABC}$ was used, with detection limit ${ }^{23,24}$ of $0.030 \mu \mathrm{g} \mathrm{mL}^{-1}$. Tables 4 and 5 show the experimental results obtained.

\section{Statistics}

Experimental data was treated by variance analysis with Tukey test at $1 \%$ for mean comparison and SANEST was the software employed for statistical analysis.

\section{RESULTS AND DISCUSSION}

Rates 2,500 and $5,000 \mu \mathrm{g} \mathrm{g}^{-1}$ of pollutant were randomly chosen due to the fact that they represent highly contaminated sludge that would be applied to soils and in $6 \mathrm{t}$ $\mathrm{ha}^{-1}$ doses. If nothing occurs with the heavy metal in percolation and exportation by plants when applied to sludge in a certain soil, the biosolids may be applied to the soil without any further concern. Such an inference may be done, since cadmium, in the form in which it has been added, is available in soil solution without any previous mineralization of the sludge's organic matter.

Although lead is found naturally on the earth crust at mean values of $12.5 \mathrm{mg}$ $\mathrm{kg}^{-125}$ and $16 \mathrm{mg} \mathrm{kg}^{-1} 26,27$, it has been constant from the very beginning of human civilization $^{28}$. In 1981 lead was the fifth element in world metal production ranking, following $\mathrm{Fe}, \mathrm{Cu}, \mathrm{Al}$ and $\mathrm{Zn}^{29}$. At present it is ubiquitous in the environment ${ }^{30-35}$. Since it is also found in sewage sludge, it has been added so that possible interferences in $\mathrm{Cd}$ behavior could be studied. 
Table 4. Production of dry matter from plant's aerial part and cadmium concentration.

\begin{tabular}{lcc}
\multicolumn{1}{c}{ Treatments } & Production in $\mathrm{g}\left(^{*}\right)$ & Cd concentration in $\mu \mathrm{g} \mathrm{g}^{-1}(\ddagger)$ \\
\hline Control & $4.22 \mathrm{a}(\ddagger)$ & $0.80 \mathrm{~b}(\ddagger)$ \\
$\mathrm{Cd}(2,500)$ & $3.79 \mathrm{a}(\ddagger)$ & $7.10 \mathrm{a}(\ddagger)$ \\
$\mathrm{Cd}(5,000)$ & $3.52 \mathrm{a}(\ddagger)$ & $6.71 \mathrm{a}(\ddagger)$ \\
$\mathrm{Cd}(2,500) \mathrm{e} \mathrm{Pb}(2,500)$ & $3.82 \mathrm{a}(\ddagger)$ & $6.70 \mathrm{a}(\ddagger)$ \\
$\mathrm{Cd}(5.000) \mathrm{e} \mathrm{Pb}(5,000)$ & $3.35 \mathrm{a}(\ddagger)$ & $9.20 \mathrm{a}(\ddagger)$ \\
\hline
\end{tabular}

$\left({ }^{*}\right)$ mean values of the experiment's three replications; ( $\left.\dagger\right)$ mean values of two analytic replications; ( $\$$ ) means followed by different letters differ at $1 \%$ level of significance.

Table 5. Mean of Cd concentration $\left(\mu \mathrm{g} \mathrm{g}^{-1}\right)$ in Red Nitosoil for triplicates of different treatments.

\begin{tabular}{|c|c|c|c|c|c|c|c|}
\hline \multirow{2}{*}{\multicolumn{2}{|c|}{$\begin{array}{l}\text { Depth } \\
\text { (cm) }\end{array}$}} & \multicolumn{6}{|c|}{ Treatments } \\
\hline & & \multicolumn{2}{|c|}{ Control } & $\begin{array}{c}\mathrm{Cd} \\
(2,500)\end{array}$ & $\begin{array}{c}\mathrm{Cd} \\
(5,000)\end{array}$ & $\begin{array}{c}(\mathrm{Cd}+\mathrm{Pb}) \\
2,500(\dagger)\end{array}$ & $\begin{array}{c}(\mathrm{Cd}+\mathrm{Pb}) \\
5,000(\ddagger)\end{array}$ \\
\hline \multicolumn{2}{|c|}{ Surface } & $4.94 \mathrm{a}$ & & $21.77 \mathrm{a}^{*}$ & $31.88 \mathrm{a}^{*}$ & $20.82 \mathrm{a}^{*}$ & $32.31 \mathrm{a}^{*}$ \\
\hline \multirow{2}{*}{20} & i & $4.88 \mathrm{a}$ & & $4.86 \mathrm{~b}^{*}$ & $4.94 \mathrm{~b}^{*}$ & $4.89 \mathrm{~b}^{*}$ & $4.85 \mathrm{~b}^{*}$ \\
\hline & e & $4.87 \mathrm{a}$ & & $4.86 \mathrm{~b}$ & $4.92 \mathrm{~b}$ & $4.88 \mathrm{~b}$ & $4.83 \mathrm{~b}$ \\
\hline \multirow[t]{2}{*}{30} & $\mathbf{i}$ & $4.87 \mathrm{a}$ & & $4.85 \mathrm{~b}$ & $4.92 \mathrm{~b}$ & $4.86 \mathrm{~b}$ & $4.83 \mathrm{~b}$ \\
\hline & e & $4.86 \mathrm{a}$ & a & $4.85 \mathrm{~b}$ & $4.89 \mathrm{~b}$ & $4.86 \mathrm{~b}$ & $4.82 \mathrm{~b}$ \\
\hline \multirow[t]{2}{*}{40} & i & $4.86 \mathrm{a}$ & $\mathrm{a}$ & $4.85 \mathrm{~b}$ & $4.88 \mathrm{~b}$ & $4.83 \mathrm{~b}$ & $4.80 \mathrm{~b}$ \\
\hline & $\mathbf{e}$ & $4.83 \mathrm{a}$ & $\mathbf{a}$ & $4.83 \mathrm{~b}$ & $4.86 \mathrm{~b}$ & $4.83 \mathrm{~b}$ & $4.79 \mathrm{~b}$ \\
\hline \multirow[t]{2}{*}{50} & $\mathbf{i}$ & $4.82 \mathrm{a}$ & $\mathrm{a}$ & $4.83 \mathrm{~b}$ & $4.86 \mathrm{~b}$ & $4.80 \mathrm{~b}$ & $4.79 \mathrm{~b}$ \\
\hline & e & $4.80 \mathrm{a}$ & $\mathrm{a}$ & $4.82 \mathrm{~b}$ & $4.86 \mathrm{~b}$ & $4.77 \mathrm{~b}$ & $4.77 \mathrm{~b}$ \\
\hline \multirow[t]{2}{*}{60} & i & $4.73 \mathrm{a}$ & $\mathrm{a}$ & $4.80 \mathrm{~b}$ & $4.83 \mathrm{~b}$ & $4.76 \mathrm{~b}$ & $4.77 \mathrm{~b}$ \\
\hline & e & $4.68 \mathrm{a}$ & $\mathrm{a}$ & $4.77 \mathrm{~b}$ & $4.82 \mathrm{~b}$ & $4.74 \mathrm{~b}$ & $4.76 \mathrm{~b}$ \\
\hline
\end{tabular}

$\mathbf{i}$ - internal part of gauge tube; $\mathbf{e}$ - external part of gauge tube; $(\uparrow)$ contamination of biosolid in treatment, in $\mu \mathrm{g} \mathrm{g}^{-1}$, for each element; ( $\ddagger$ contamination of biosolid in treatment, in $\mu \mathrm{g} \mathrm{g}^{-1}$, for each element; ${ }^{*}$ means followed by different letters differ at $1 \%$ significant level.

\section{Maize plants}

Maize plants were harvested 75 days after germination since they exhibited certain deficiencies: leaves began to turn purple, probably due to P deficiency; later, they manifested yellowing symptoms (chlorosis), probably due to $\mathrm{N}$ deficiency, according to Kabata-Pendias \& Pendias ${ }^{36}$. Table 4 shows the dry part of the aerial part of the plant. Variance analysis failed to show any significant difference in dry matter production.

Cd concentration in the aerial part of plant (Table 4) shows that Red Nitosoil soil had similar values, including treatments in which $\mathrm{Pb}$ has been employed as interference factor. It differed, however, from the control in which the least absorption by plant occurred owing to less availability or to low concentration.

Lake $(1987)^{37}$ states that absorption of $\mathrm{Cd}$ applied with sewage sludge immediately before planting is at least 10 times higher than that when sowing is done in sludge-treated soils during consecutive years. 
According to Kabata-Pendias \& Pendias (1992) ${ }^{36}$, cadmium may have the following concentration rates in the dry tissues of mature leaves for different species: a) normal or sufficient concentration, from 0.05 to $0.2 \mu \mathrm{g} \mathrm{g}^{-1} ; \mathrm{b}$ ) excessive or toxic, from 5 to $\left.30 \mu \mathrm{g} \mathrm{g}^{-1} ; \mathrm{c}\right)$ tolerated in agronomic species, $2 \mu \mathrm{g} \mathrm{g}^{-1}$. Experimentally obtained rates are found within the phytotoxic range (Table 4). Cadmium concentration in the control was lower than that tolerable, albeit above normal.

\section{Cadmium in the soil}

Results of Red Nitosoil soil treated with either contaminated or noncontaminated sewage sludge (Table 5) showed an accumulation of heavy metal at the surface $(0-20 \mathrm{~cm}$ depth level) where contaminated sewage sludge was applied in all treatments. Heavy metals generally fix themselves at $0-20 \mathrm{~cm}$ depth layer, precisely the layer with the highest fertility index and, obviously, greatly used in agriculture ${ }^{38}$.

Analyzing interactions between humus acids and heavy metals, Ladonin and Margolina $(1997)^{39}$ present a hypothesis for heavy metal retention. They admit a chemical fixation between the active sites of humus acids and metals.

Such a "fixation", or rather, a chemical link, occurs by the formation of external or internal layer complexes ${ }^{40}$. Interactions between cadmium cation and the simple or homologue composite ligand within the external layer are electrostatic according to [1]:

$$
\begin{aligned}
\mathrm{Cd}_{\mathrm{aq}}{ }^{(2+)}+\mathrm{L}_{\mathrm{aq}} \rightleftarrows \quad & \left\{\left[\mathrm{Cd}_{\mathrm{aq}}{ }^{(2+)} \ldots \mathrm{L}_{\mathrm{aq}}{ }^{(\mathrm{n})}\right]^{[(\mathrm{n}-)+(2+)]}\right\}_{\mathrm{aq}} \\
& \text { electrostatic interaction }
\end{aligned}
$$

where $\mathrm{L}$ is the ligand which may be either a simple composite $\left(\mathrm{Cl}{ }^{-}, \mathrm{CO} 3^{2-}, \mathrm{PO}^{3-}\right.$, amino-acids etc) or a homologous composite (fulvic and humic acids, proteins, metallic oxides and hydroxides etc).

In the internal layer complexes the interaction between cadmium and the ligand is covalent [2]:

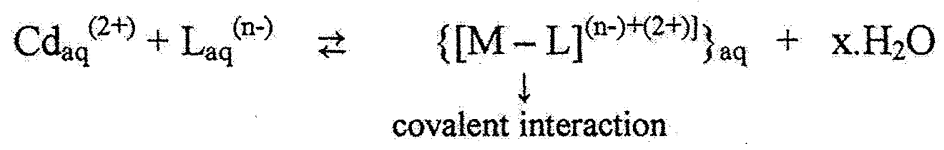

In all treatments $\mathrm{Cd}$ concentrations comprising horizontal direction, external and internal parts of the gauge tubes, and vertical direction, $20-60 \mathrm{~cm}$ depth layer, did not have statistically significant differences. They were compatible with control and thus confirm that neither lixiviation nor diffusion of heavy metals occurred in these directions. A similar study with cadmium in Dark Red Latosol showed the same conclusion $^{41}$.

Although clay makes up $52 \%$ of soil (Table 1), its cationic change capacity amounts to $13.51 \mathrm{smol}_{\mathrm{c}} \mathrm{dm}^{3}$ (Table 2). This is rather low when compared to certain types of clay and shows slightly expansive clay ${ }^{7}$.

Studies on metal movements in soils treated with organic residues suggest that less than $1 \%$ of metals may be lixiviated. These metals may either be adsorbed or made more complex, till changes occur in the system ${ }^{42}$. This fact has been detected in current experiment since cadmium was not found in percolation water in the soil of the PVC column when irrigation, imitating torrential rain, was executed weekly. 


\section{SOUTH. BRAZ. J. CHEM., Vol. 11, No 12, 2003}

When data in Tables 4 and 5 are analyzed with regard to treatments for possible $\mathrm{Pb}$ interference in $\mathrm{Cd}$, it has been observed that the former failed to change $\mathrm{Cd}$ behavior in any treatment.

\section{CONCLUSIONS}

The experimental results led to the following conclusions:

The heavy metal $\mathrm{Cd}$ in soil was retained at the arable soil level $(0-20 \mathrm{~cm}$ depth $)$ in all treatments.

No significant difference occurred in the production of dry matter from the aerial part of plants.

When $\mathrm{Cd}$ absorption by the aerial part of maize plants is taken into account, $\mathrm{Cd}$ concentration rate maintained itself at the starting level of phytotoxic concentrations.

Lixiviation and metal diffusion have not been observed in layers below the arable level.

$\mathrm{Pb}$ interference with $\mathrm{Cd}$ behavior has not been detected in any soil or plant parameter.

\section{REFERENCES}

1 B. van Raij, Fertilidade do Solo e Adubação [Soil Fertility and Manuring]. Editora Agronômica Ceres Ltda., Piracicaba, SP (1991), 343 p.

2 E. Malavolta, Elementos de Nutrição Mineral das Plantas [Elements of Plants' Mineral Nutrition]. Editora Agronômica Ceres Ltda., São Paulo (1980), p.16-17.

3 IPT (Instituto de Pesquisas Tecnológicas). Lixo Municipal - Manual de Gerenciamento Integrado [Municipal Garbage - Handbook for Integrated Management]. Instituto de Pesquisas Tecnológicas de São Paulo, São Paulo (1995), 278 p.

4 L. M. Q. Lima, Tratamento do Lixo [Treatment of Garbage]. HEMUS Editora Ltda., São Paulo (1985), p.09-15.

5 L. C. B. Przybysz, e E. F. Guidi, Sanare, 7(7), 20-23 (1997).

6 P. Alem Sobrinho, Tratamento de esgoto e geração de lodo [Sewage Treatment and Sludge Production]. In: W. Bettiol e O. A. Camargo, (Ed.) Impacto Ambiental do Uso Agrícola do Lodo de Esgoto. EMBRAPA - Empresa Brasileira de Pesquisas Agropecuárias, Brasília, DF (2000), 312 p.

7 N. C. Brady, Natureza e Propriedades dos Solos. 7. ed., Translation of The Nature and Properties of Soils, 9. ed., Livraria Freitas Bastos S. A., Rio de Janeiro (1989).

8 B. J. Alloway, (Ed.) Heavy Metals in Soils. John Wiley \& Sons, Inc., New York (1990), p. $103-118$.

9 W. Bettiol e O. A. Camargo, (Ed.) Impacto Ambiental do Uso Agrícola do Lodo de Esgoto [Environmental Impact of Agricultural Use of Sewage Sludge]. EMBRAPA Empresa Brasileira de Pesquisas Agropecuárias, Brasília, DF (2000), 312 p.

10 C. V. Andreoli, A. I. Lara, e F. Fernandes, (Ed.) Reciclagem de Biossólidos Transformando Problemas em Soluções [Recycling Biosolids - Changing Problems into Solutions]. SANEPAR - Companhia de Saneamento do Paraná, Curitiba, PR (1999), $300 \mathrm{p}$.

11 M. B. McBride, J. Quality, 24, 5-18 (1995). 


\section{SOUTH. BRAZ. J. CHEM., Vol. 11, No 12, 2003}

12 V. M. Goldschmidt, Apud: McLaughlin, M.J.; Tiller K.G.; Naidu R.; Stevens D.P.. J. Soil Res., 34, 11-26 (1996).

13 W. L. Lindsay. Apud: M. J. McLaughlin, K. G. Tiller, R. Naidu, D. P. STevens, J. Soil Res., 34, 11-26 (1996).

14 E. Brams and W. Anthony, Plant and Soil, 109, 3-8 (1988).

15 F. C. SLlVA, Uso Agronômico do lodo de esgoto. Efeito na fertilidade do solo e qualidade da cana-de-açúcar [Agronomic Use of Sewage Sludge. Effects on Soil Fertility and Sugarcane Quality]. 1995. Doctoral Thesis at the Escola Superior de Agricultura "Luíz de Queiroz" - Campus Piracicaba, USP, SP (1995).

16 N. Horwitz, (Ed.) Official Methods of Analysis of the Association of Official Analytical Chemists. 13. ed., Association of Official Analytical Chemists (AOAC), Washington (1980), $1018 \mathrm{p}$.

17 D. A. Skoog, D. M. West and F. J. Holler, Fundamentals of Analytical Chemistry. 6. ed., Saunders College Publishing, Philadelphia, USA (1992).

18 EMBRAPA, Manual de Métodos de Análise de Solo [Handbook of Methods for Soil Analysis]. 2. ed., EMBRAPA-CNPS, Rio de Janeiro (1997), p.141-142.

19 P. M. B. Braile e J. E. W. A. Cavalcanti, Manual de Tratamento de águas Residuais Industriais [Handbook of Treatment for Industrial Residual Water]. Companhia de Tecnologia de Saneamento Ambiental - CETESB, São Paulo (1993), p.42-44.

20 E. Malavolta, Manual de Química Agrícola, Adubos e Adubações [Handbook of Agricultural Chemistry, Manures and Fertilization]. 3rd ed., Editora Agronômica CERES Ltda., São Paulo (1981), 596 p.

21 MINISTÉRIO DA AGRICULTURA. Manual de Observação de Superficie [Handbook for Soil Surface Analysis]. Instituto Nacional de Meteorologia, Brasília, DF (1977).

22 R. O. Scott, R. L. Mitchel, D. Purves and C. Loss, Spectrochemical Methods for the Analysis of Soils, Plants and Agricultural Materials. The Macaulay Institute for Soil Research, Aberdeen (1971), p. 9-16.

23 B. Welz, M. Sperling, Atomic Absorption Spectrometry. 3. rev. ed. Weinheim (Germany): VCH Verlagsgesellschaft mbH (1999), $941 \mathrm{p}$.

24 Analytical Methods Committee, Analyst, 112, 199-204 (1987).

25 S. R. Taylor, Geochim. Cosmochim. Acta, 28, 1273-1285 (1965).

26 P. J. Craig,. Metal cycles and Biological Methylation. In: D. Hutzinger, The Handbook of Environmental and Biogeochemical Cycles. Springer-Verlag, Berlin (1980), p.170227.

27 J. D. Lee, Química Inorgânica. [Inorganic Chemistry]. Translation of the 3rd edition by MAAR, J. H., Editora Edgard Blücher Ltda., São Paulo (1980), p.484.

28 R. L. Boekx, Anal. Chem. 58(2), 274A-287A (1986).

29 Kirk-Othmer Encyclopedia of Chemical Technology. 3. ed., John Wiley Sons, New York (1981), V. 14, p. $98-200$.

30 D. C. Adriano, Trace Elements in the Terrestrial Environment. Springer-Verlag, Berlin (1986), $533 \mathrm{p}$.

31 B. E. DAVIES. Lead. In: B. J. Alloway, Heavy Metals in Soils. Blackie and John Wiley \& Sons, Inc, London (1990), p. 177-194.

32 D. Purves, Trace - Element Contamination of the Environment. Rev. ed., Elsevier Science Publishing Company Inc., Amsterdam (1985), p. 57-61.

33 R. H. Daines, H. Motto, and D. M. Chilko, Environ. Sci. \& Technol., 4(4), 318-322, (1970). 
34 E. A. Schuck and J. K. Locke, Environ. Sci. Technol., 4(4), 325-330 (1970).

35 R. G. Smith, J. Szajnar and L. Hecker, Environ. Sci. Technol., 4,(4), 333-338 (1970).

36 A. Kabata-Pendias and H. Pendias, Trace Elements in Soils and Plants. 2. ed. CRC PRESS, Inc., Boca Raton, Florida, USA (1992), 365 p.

37 D. J. Lake. Apud: F. B. F. Egreja, Avaliação da ocorrência e distribuição química de metais pesados na compostagem do lixo domiciliar urbano [Evaluation of the Occurrence and Chemical Distribution of Heavy Metals in the Formation of Urban Domestic Garbage]. 1993. Doctoral Thesis at the Universidade Federal de Viçosa, Viçosa, MG (1993).

38 L. K. Sadounikova and N. G. Zyrin. Apud: F. B. F. Egreja, Avaliação da ocorrência e distribuição química de metais pesados na compostagem do lixo domiciliar urbano. 1993. [Evaluation of the Occurrence and Chemical Distribution of Heavy Metals in the Formation of Urban Domestic Garbage]. 1993. Doctoral Thesis at the Universidade Federal de Viçosa, Viçosa, MG (1993).

39 D. V. Ladonin, and S. E. Margolina, Eurasian Soil Sci., 30, 710-715 (1997).

40 J. Buffle, Complexation Reactions in Aquatic Systems: an Analytical Approach: ELLIS HORWOOD Limited, London (1990), 691 p.

41 S: N. Souza, Avaliações de parâmetros referentes ao Cádmio (Cd) em dois tipos de solos com aplicação do lodo de esgoto contaminado pelo mesmo [Evaluation of Cd Parameters in Two Types of Soil with the Application of Self-Contaminated Sewage Sludge]. 1998. Master's Thesis at the Universidade Estadual de Maringá, Maringá, PR, (1998).

42 T. Schirado, I. Vergara, E. B. Schalscha and P. F. Pratt, J. Environ. Quality, 15, 9-12 (1986).

43 R. L. Folk, Sedimentology; 6, 73-93 (1966).

$44 \mathrm{R}$. L. Suguio, Introdução à Sedimentologia [Introduction to Sedimentology], Editora Edgard Blücher Ltda., São Paulo, SP (1973), p.27. 